\title{
Editorial
}

Digestion

\section{Nutrients and Gut Health}

\author{
Rémy Meier \\ Gastroenterology, Hepatology and Nutritional Department, University Clinic, Kantonsspital Liestal, \\ Liestal, Switzerland
}

Inflammatory bowel diseases (IBD), such as ulcerative colitis, pouchitis and Crohn's disease, are chronic inflammatory disorders caused by increased oxidative and metabolic stress. In the last decade, an increase of the incidence rates in different areas of the world has been reported. This also happened in countries (particularly in Asia) where IBD was previously uncommon. It is unclear if the rise of the incidence in this part of the world is due to improved diagnosis methods or environmental triggers.

The exact etiology of IBD is still not clear, but it seems that a genetic predisposition, an exaggerated immune response to environmental triggers (e.g. nutritional components, infections) and the composition of the intestinal bacteria are involved $[1,2]$. None of these alone is sufficient or essential to cause the typical intestinal lesions. In the gut, bacteria, the intestinal barrier and the intestinal immune system are a close entity. It is well known from experimental models that without intestinal bacteria no IBD can develop $[3,4]$. The composition of the different bacteria is very important [5]. A reduction of the commensal lactobacilli and bifidobacteria can lead to decreased fermentation of unabsorbed carbohydrates with less production of short-chain fatty acids. Butyrate is an important source of energy for the epithelial cells and is able to downregulate inflammation by decreasing the production of proinflammatory cytokines [6, 7]. In addition, the production of antimicrobial bacteriocins can be decreased [8].

The intestinal barrier is a functional unit including the epithelial cells, mucus and different secreted substances such as defensins, lysozymes and immunoglobulins (e.g. IgA). These components are important to control the microbial composition in the gut. IgA can bind bacteria and viruses, and the defensins have direct antimicrobial activities against bacteria [9-11].

The innate and acquired intestinal immune systems are able to differentiate between the beneficial and harmful bacteria and are therefore essential for the immune homeostasis in the gut. There is constant crosstalk between the intestinal bacteria and the innate immune system. The information is transmitted through specific pattern-recognition receptors (e.g. NOD- and Toll-like receptors) [12].

Patients with IBD have a loss of tolerance to their own intestinal bacteria. It is known that patients with IBD have a decreased number of beneficial bacteria and an increased number of pathogenic bacteria adherent to the mucosa and within the epithelium [2]. It appears that these bacteria trigger a strong mucosal immunological response leading to inflammation and intestinal epithelial cell injury, mediated by activated $\mathrm{T}$ cells, mononucle-

\section{KARGER}

Fax +4161306 1234 E-Mail karger@karger.ch www.karger.com
(C) 2011 S. Karger AG, Basel

0012-2823/11/0842-0085\$38.00/0

Accessible online at:

www.karger.com/dig
Prof. Rémy Meier, MD

Gastroenterology, Hepatology and Nutritional Department, University Clinic

Kantonsspital Liestal, Rheinstrasse 26

CH-4410 Liestal (Switzerland)

Tel. +41 61925 2187, E-Mail remy.meier@ ksli.ch 
ar cells and macrophages. If this response cannot be downregulated by regulatory $\mathrm{T}$ cells, numerous inflammatory cytokines are activated by stimulation of the intercellular transcription factor NF-kB. It has been shown that bacterial lipopolysaccharides or peptidoglucans can activate NF- $\mathrm{kB}$ by binding to specific pattern recognition receptors [12]. It is still unknown why the proinflammatory response cannot be downregulated and why the inflammatory drive continuously leads to mucosal damage resulting either in Crohn's disease or ulcerative colitis.

In the whole process of inducing or prolonging inflammatory process, it seems possible that nutritional components can be involved. It is well known that the specific metabolites from nutrients can change the composition of the intestinal bacteria. This can be involved in the pathogenesis of IBD, and can also help treat or prolong remission in IBD.

The article by Ioannidis et al. [13] in this issue of Digestion describes several possible mechanisms of different nutrients which can be involved. Specific nutrients are able to regulate the intestinal bacteria, sequestrate intraluminal antigens, modulate the immune response, increase the antioxidant status, stimulate production of short-chain fatty acids and regulate intestinal motility. The balance between oxidative and antioxidative agents is crucial for the immune functions of cells because it preserves the integrity and function of the cellular membrane, cellular proteins and nucleic acids as well as controls intracellular signaling and gene expression [14]. Among the antioxidants, glutathione is very important. There is evidence that oxidative stress promotes cellular apoptosis and that antioxidants could have a protective role. Although there are candidates of nutritional additives, such as selenium, glutamine or cysteine, which can increase glutathione levels, there are no good clinical data to prove this concept. The same is true for other antioxidants such as vitamins (A, C, E).

Different lipids are very important. Dietary lipids induce changes in cell membrane phospholipids, which, in response to an inflammatory trigger, synthesize eicosanoids with different degrees of pro- or anti-inflammatory activities through up- or downregulation of the expression of pro- or anti-inflammatory cytokines and adhesion molecules [15]. Several lipid compositions in diets were studied in Crohn's disease, but the results are still controversial. Enteral diets with a low content of longchain triglycerides, or in diets where part of the longchain triglycerides were replaced with medium-chain triglycerides, did not achieve clear beneficial effects [16]. In a Cochrane analysis, no clear benefit could be demon- strated for low-fat diets compared to high-fat diets [17]. Different types of long-chain triglycerides were compared: one was high in oleate and the other was high in linoleate in patients with active Crohn's disease. The remission rates with linoleate were significantly higher than with oleate [18]. The effect of n-3 fatty acids (e.g. fish oil) on the inflammatory response was studied in Crohn's disease and ulcerative colitis. The reported effect showed mixed results. A systemic review of 13 controlled trials showed that fewer than 6 were identified that assessed the effects of n-3 fatty acids on single outcome parameters. In 3 studies, a reduction of corticosteroid requirements was found, although statistical significance was shown in only one of these studies.

At present, it is not possible to draw a clear conclusion regarding the effects of $\mathrm{n}-3$ fatty acids on clinical, endoscopic and histological scores, or on remission and relapse rates [19]. The effects of different types of lipids on inflammatory activity deserve further studies. Furthermore, after an initial study showing great benefits of diet supplementation with $\mathrm{n}-3$ fatty acids containing entericcoated capsules in Crohn's disease, there was a great hope to reduce relapses [20]. These beneficial effects, however, could not be reproduced in 2 large, recently published studies [21].

In the last decade, there was much hope that different fiber (prebiotics) and probiotics could be a corner stone in modulating the immune response in IBD patients. Prebiotics are soluble poly- or oligosaccharides (inulin, pectin, fructo- and galacto-oligosaccharides) and serve in the intestine as substrates for fermentation [22]. Probiotics are nonpathogenic bacteria which are able to exert positive health benefits in the gastrointestinal tract. They are able to adhere to the intestinal mucosa and can stimulate the secretion of IgA and mucus production. They may reduce the levels of proinflammatory cytokines (TNF- $\alpha$, IL-1, IL-6) and increase levels of anti-inflammatory cytokines (IL-10, TGF- $\beta$ ). Furthermore, they can induce defensin secretion and increase heat shock proteins [23-26].

Pre- and probiotics can interact with the commensal intestinal bacteria and may therefore influence the intestinal ecosystem. This effect is eminent in the colon, where anaerobic bacteria can ferment nonabsorbable dietary carbohydrates. Through fermentation, the intestinal $\mathrm{pH}$ decreases, which stimulates the growth of nonpathogenic bacteria (prebiotic effect) and liberates short-chain fatty acids. Butyrate prevents the expression of specific genes and coding cytokines from intensifying the inflammatory response. In addition, butyrate increases apoptosis of inflammatory cells $[27,28]$. 
So far, the use of pre- and probiotics was found to be more beneficial in ulcerative colitis than in Crohn's disease. The use of fermentable fiber supplementation achieved similar remission rates in ulcerative colitis as mesalazine [29]. In several studies, administration of Escherichia coli Nissle 1917 and Lactobacillus GG was compared with mesalazine in ulcerative colitis. In these studies, probiotics maintained remission at similar rates as mesalazine [30-32]. Good clinical results were also published using probiotics in patients with pouchitis. A combination of eight different bacteria compared to placebo showed that relapses of pouchitis and the development of pouchitis after surgery could be reduced $[33,34]$. The article by Ioannidis et al. [13] describes the different possible nutrition-derived mechanisms involved in the pathogenesis of IBD well. In addition, it offers an excellent summary of the possible preventive and treatment options using different nutrients in IBD patients.

Although there are many good studies in cell culture and in animals using specific nutrients, there are still a lot of unanswered questions. I am sure that continuing research will show us that we can partially change the history of IBD by using specific nutrients in the future. The most promising substrates are nutritional additives, which can change the composition of the intestinal bacteria. There is still a lot of work to be done. The abovementioned article is very interesting and important for scientists and practitioners interested in IBD.

\section{References}

1 Podolsky DK: Inflammatory bowel disease. N Engl J Med 2002;347:417-429.

-2 Swidsinsky A, Ladoff A, Pernthaler A, et al: Mucosal flora in inflammatory bowel disease. Gastroenterology 2002;122:44-54.

3 Kuhn R, Lohler J, Rennick D, Rajewsky K, Muller W: Interleukin-10-deficient mice develop chronic enterocolitis. Cell 1993;75: 263-274.

-4 Sadlack, B, Merz H, Schorle H, Schimpl A, Feller AC, Horak I: Ulcerative colitis-like disease in mice with a disrupted interleukin-2 gene. Cell 1993;75:253-261.

$\checkmark 5$ Madsen KL, Doyle JS, Jewell LD, et al: Lactobacillus species prevents colitis in interleukin 10 gene-deficient mice. Gastroenterology 1999;116:1107-1114.

-6 Segain JP, Raingeard de la Blétière D, Bourreille $A$, et al: Butyrate inhibits inflammatory responses through NFkappaB inhibition: implications for Crohn's disease. Gut 2000;47:397-403

7 Venkatraman A, Ramakrishna BS, Shaji RV, Kumar NS, Pulimood A, Patra S: Amelioration of dextran sulfate colitis by butyrate: role of heat shock protein 70 and NF-kappaB. Am J Physiol Gastrointest Liver Physiol 2003;285:G177-G184.

-8 Corr SC, Li Y, Riedel CU, et al: Bacteriocin production as a mechanism for the antiinfective activity of Lactobacillus salivarius UCC118. Proc Natl Acad Sci USA 2007;104: 7617-7621.

9 Meyer-Hoffert U, et al: Secreted enteric antimicrobial activity localises to the mucus surface layer. Gut 2008;57:764-771.

10 Wehkamp J, et al: Defensin deficiency, intestinal microbes, and the clinical phenotypes of Crohn's disease. J Leukoc Biol 2005;77: 460-465.
11 Lehrer IR, et al: Defensins: antimicrobial and cytotoxic peptides of mammalian cells. Annu Rev Immunol 1993;11:105-128.

12 Sartor RB: Induction of mucosal immune responses by bacteria and bacterial components. Curr Opin Gastroenterol 2001;17: 555-561.

13 Ioannidis O, Varnalidis I, Paraskevas G, Botsios D: Nutritional modulation of the inflammatory bowel response. Digestion 2011;84:89-101.

14 Knight JA: Review: free radicals, antioxidants, and the immune system. Ann Clin Lab Sci 2000;30:145-158.

15 Gassull MA: Review article: the role of nutrition in the treatment of inflammatory bowel disease. Aliment Pharmacol Ther 2004; 20(suppl 4):79-83.

16 Sakura T, Matsui T, Yao T, et al: Short-term efficacy of enteral nutrition in the treatment of active Crohn's disease: a randomized, controlled trial comparing nutrient formulas. J Parenter Enteral Nutr 2002;6:98-103.

17 Zacos M, Tondeur M, Griffiths AM: Enteral nutritional therapy for inducing remission of Crohn's disease. Cochrane Database Syst Rev 2001;3:CD000542.

-18 Khoshoo V, Reifen R, Neuman MG, Griffiths A, Pencharz PB: Effect of low- and high-fat, peptide-based diets on body composition and disease activity in adolescents with active Crohn's disease. J Parenter Enteral Nutr 1996;20:401-405.

19 MacLean CH, Mojica WA, Newberry SJ, et al: Systematic review of the effects of n-3 fatty acids in inflammatory bowel disease. Am J Clin Nutr 2005;82:611-619.

20 Belluzzi A, Brignola C, Campieri M, Pera A, Boschi S, Miglioli M: Effect of an entericcoated fish-oil preparation on relapses in Crohn's disease. N Engl J Med 1996;334: $1557-1560$.
-21 Feagan BG, Sandborn WJ, Mittmann U, et al: Omega-3 free fatty acids for the maintenance of remission in Crohn disease: the EPIC Randomized Controlled Trials. JAMA 2008;299:1690-1697.

$\checkmark 22$ Hammes WP, Hertel C: Research approaches for pre- and probiotics: challenges and outlook. Food Res Int 2002;35:165-170.

23 Johansson ML, Molin G, Jeppsson B, Nobaek S, Ahrné S, Bengmark S: Administration of different Lactobacillus strains in fermented oatmeal soup: in vivo colonization of human intestinal mucosa and effect on the indigenous flora. Appl Environ Microbiol 1993;59: 15-20.

24 Molin G, Jeppsson B, Johansson ML, et al: Numerical taxonomy of Lactobacillus spp. associated with healthy and diseased mucosa of the human intestines. J Appl Bacteriol 1993;74:314-323.

25 Schiffrin EJ, Rochat F, Link-Amster H, Aeschlimann JM, Donnet-Hughes A: Immunomodulation of human blood cells following the ingestion of lactic acid bacteria. J Dairy Sci 1995;78:491-497.

26 Link-Amster H, Rochat F, Saudan KY, Mignot O, Aeschlimann JM: Modulation of a specific humoral immune response and changes in intestinal flora mediated through fermented milk intake. FEMS Immunol Med Microbiol 1994;10:55-63.

-27 Inan MS, Rasoulpour RJ, Yin L, Hubbard AK, Rosenberg DW, Giardina C: The luminal short-chain fatty acid butyrate modulates NF-kappaB activity in a human colonic epithelial cell line. Gastroenterology 2000; 118:724-734. 
-28 Lévy P, Robin H, Bertrand F, Kornprobst M, Capeau J: Butyrate-treated colonic Caco-2 cells exhibit defective integrin-mediated signaling together with increased apoptosis and differentiation. J Cell Physiol 2003;197:336347.

-29 Fernández-Bañares F, Hinojosa J, SánchezLombraña JL, et al: Randomized clinical trial of Plantago ovata seeds (dietary fiber) as compared with mesalamine in maintaining remission in ulcerative colitis. Spanish Group for the Study of Crohn's Disease and Ulcerative Colitis (GETECCU). Am J Gastroenterol 1999;94:427-433.
30 Rembacken BJ, Snelling AM, Hawkey PM, Chalmers DM, Axon AT: Non-pathogenic Escherichia coli versus mesalazine for the treatment of ulcerative colitis: a randomised trial. Lancet 1999;354:635-639.

-31 Kruis W, Fric P, Pokrotnieks J, et al: Maintaining remission of ulcerative colitis with the probiotic Escherichia coli Nissle 1917 is as effective as with standard mesalazine. Gut 2004;53:1617-1623.
2 Zocco MA, dal Verme LZ, Cremonini F, et al: Efficacy of Lactobacillus GG in maintaining remission of ulcerative colitis. Aliment Pharmacol Ther 2006;23:1567-1574.

>33 Gionchetti P, Rizzello F, Venturi A, et al: Oral bacteriotherapy as maintenance treatment in patients with chronic pouchitis: a double-blind, placebo-controlled trial. Gastroenterology 2000;119:305-309.

34 Gionchetti P, Rizzello F, Helwig U, et al: Prophylaxis of pouchitis onset with probiotic therapy: a double-blind, placebo-controlled trial. Gastroenterology 2003;124:1202-1209. 